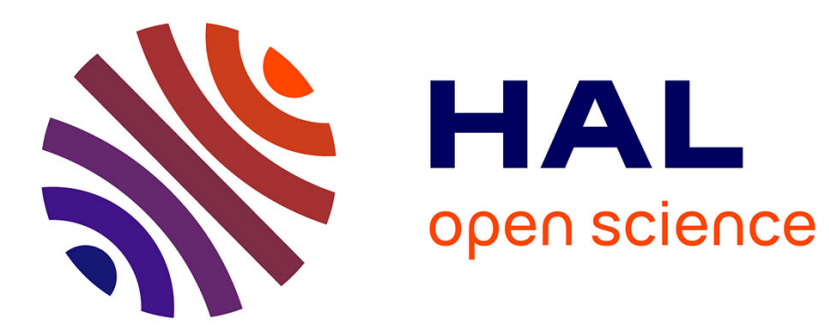

\title{
BEHAVIOUR OF GERMANIUM IN PHASE SEPARABLE GLASSES OF THE SYSTEM Na2O - $\mathrm{B} 2 \mathrm{O} 3$ - $\mathrm{GeO} 2$ - $\mathrm{SiO} 2$
}

\author{
F. Gauthier, Corentin J Lapeyre, J. Gombert
}

\section{- To cite this version:}

F. Gauthier, Corentin J Lapeyre, J. Gombert. BEHAVIOUR OF GERMANIUM IN PHASE SEPARABLE GLASSES OF THE SYSTEM Na2O - B2O3 - GeO2 - SiO2. Journal de Physique Colloques, 1982, 43 (C9), pp.C9-253-C9-256. 10.1051/jphyscol:1982946 . jpa-00222475

HAL Id: jpa-00222475

https://hal.science/jpa-00222475

Submitted on 1 Jan 1982

HAL is a multi-disciplinary open access archive for the deposit and dissemination of scientific research documents, whether they are published or not. The documents may come from teaching and research institutions in France or abroad, or from public or private research centers.
L'archive ouverte pluridisciplinaire HAL, est destinée au dépôt et à la diffusion de documents scientifiques de niveau recherche, publiés ou non, émanant des établissements d'enseignement et de recherche français ou étrangers, des laboratoires publics ou privés. 
JOURNAL DE PHYSIQUE

Colloque C9, supp zément au $n^{\circ} 12$, Tome 43, décembre 1982

page c9-253

BEHAVIOUR OF GERMANIUM IN PHASE SEPARABLE GLASSES OF THE SYSTEM $\mathrm{Na}_{2} \mathrm{O}-\mathrm{B}_{2} \mathrm{O}_{3}-\mathrm{GeO}_{2}-\mathrm{SiO}_{2}$

F. Gauthier, C. Lapeyre and J. Gombert

Thomson-C.S.F. - Laboratoire Central de Recherches, Domaine de Corbevizle, B.P. 10, 91401 Orsay Cedex, France

Résumé - Le rôle de $\mathrm{GeO}_{2}$ dans le quaternaire $\mathrm{Na}_{2} \mathrm{O}-\mathrm{B}_{2} \mathrm{O}_{3}-\mathrm{GeO}_{2}-\mathrm{SiO}_{2}$ qui présente un domaine de séparation de phases spinodale est abordé. Les propriétês physiques de ce système sont comparées à celles des borosilicates de sodium. Les conditions de lessivabilité des verres sont examinées. La coordinance du germanium a été étudiée dans un verre brut et dans le verre lixivié correspondant.

Abstract - The rôle of $\mathrm{GeO}_{2}$ in the $\mathrm{Na}_{2} \mathrm{O}-\mathrm{B}_{2} \mathrm{O}_{3}-\mathrm{GeO}_{2}$ - $\mathrm{SiO}_{2}$ quaternary system which presents a spinodal decomposition domain is studied. The physical properties of this system are compared to those of the system without $\mathrm{GeO}_{2}$. The leaching conditions of these glasses and the coordination of Ge are studied.

I. INTRODUCTION

The mechanism of phase separation by spinodal decomposition is used in the Vycor ${ }^{R}$ process to obtain $96 \%$ silica rich glasses from base glass of the $\mathrm{Na}_{2} \mathrm{O}-\mathrm{B}_{2} \mathrm{O}_{3}-\mathrm{SiO}_{2}$ system. In order to prepare $\mathrm{GeO}_{2}-\mathrm{SiO}_{2}$ slasses, phase separation by spinodaI decomposition has been studied in the $\mathrm{Na}_{2} \mathrm{O}-\mathrm{B}_{2} \mathrm{O}_{3}-\mathrm{GeO}_{2}-\mathrm{SiO}_{2}$ system. This paper reviews some physical and chemical properties of these glasses. Interpreting the leaching mechanism, and EXAFS studies of the germanium coordination, the rôle of GeO 2 is shown.

II. PROPERTIES OF GLASSES OF THE QUATERNARY SYSTEM

Base glass preparation: The glasses were melted in a platinum $10 \%$ rhodium crucible in oxidizing atmosphere. The starting raw materials were "ultrapure" grade quality silica, germanium oxide, borax and boric oxide or boric acid. Melting temperature ranged between 1100 and $1350^{\circ} \mathrm{C}$ depending on the silica content.

Phase - separated leachable glass compositions: Fig. 1 (1) represents the domain of immiscibility in the quaternary system. The leachable glass compositions in the $\mathrm{Na}_{2} \mathrm{O}-\mathrm{B}_{2} \mathrm{O}_{3}-\mathrm{SiO}_{2}$ system lie in the $V_{y c o r}{ }^{R}$ optimum line. In the vicinity of the line the densities of the glasses show an unusual behaviour Fig. 2a $(2-3)$. In the quaternary composition plane with $\mathrm{SiO}_{2}=54 \%$ (mole) Fig. 2b - densities show identical properties (4). The $\mathrm{Na}_{2} \mathrm{O} / \mathrm{Na}_{2} \mathrm{O}+\mathrm{B}_{2} \mathrm{O}_{3}$ ratio for leachable glasses in the quaternary system $\mathrm{Na}_{2} \mathrm{O}-\mathrm{B}_{2} \mathrm{O}_{3}-\mathrm{GeO}_{2}-\mathrm{SiO}_{2}$ is identical to the corresponding one in the $\operatorname{Vycor}^{\mathrm{R}}$ optimum line - Fig. 3 - The presence up to 20 mole \% of $\mathrm{GeO}_{2}$ does not drastically modify the leaching behaviour of the corresponding borosilicate.

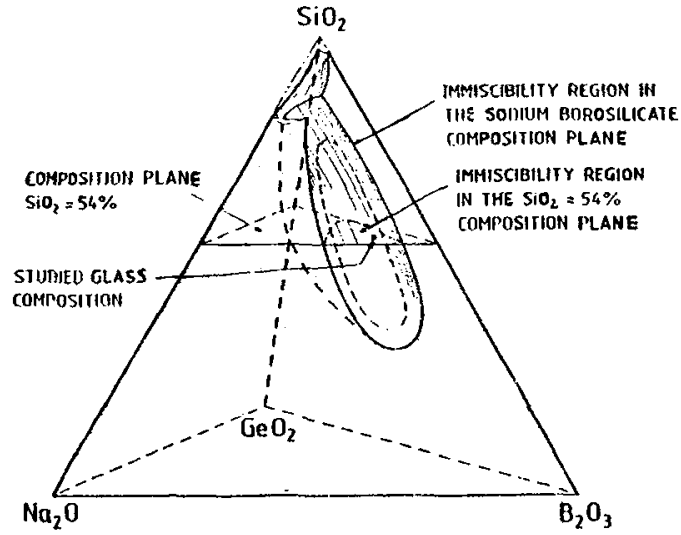

FIG. 1 : INMISCIBILITY REGION IN THE $\mathrm{Na}_{2} \mathrm{O}-\mathrm{B}_{2} \mathrm{O}_{3}-\mathrm{GeO}_{2}-\mathrm{SiO}_{2}$ SYSTEM 

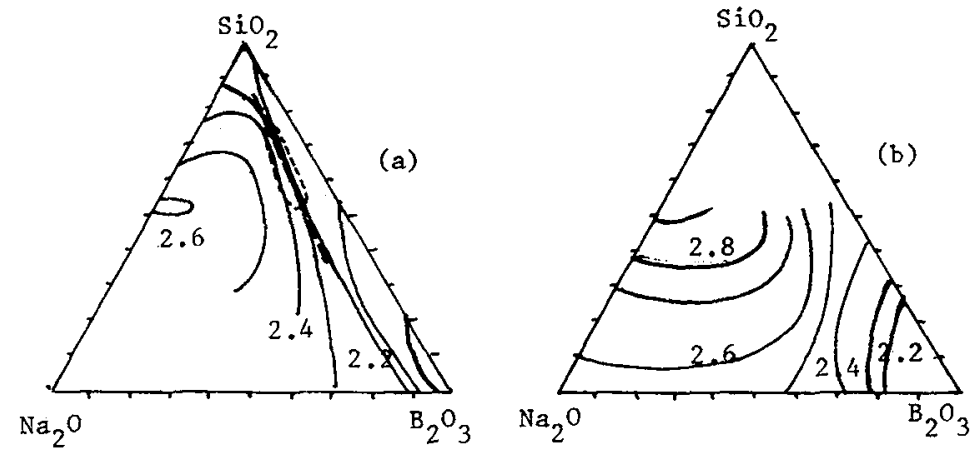

FIG.2: GLASS DENSITY (a) $\mathrm{Na}_{2} \mathrm{O}-\mathrm{B}_{2} \mathrm{O}_{3}-\mathrm{SiO}_{2}(2-3)$

(b) $\mathrm{Na}_{2} \mathrm{O}-\mathrm{B}_{2} \mathrm{O}_{3}-\mathrm{GeO}_{2}-\mathrm{SiO}_{2}=54 \%$

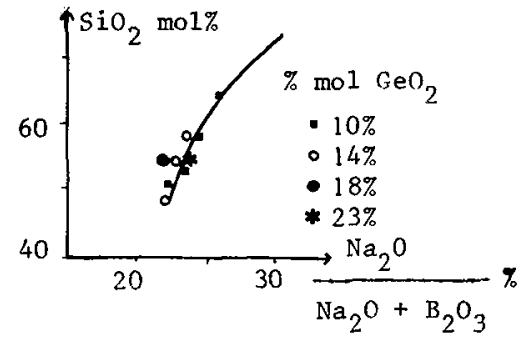

FIG.3: CORRESPONDING OPTIMUM LINE IN THE QUATERNARY SYSTEM

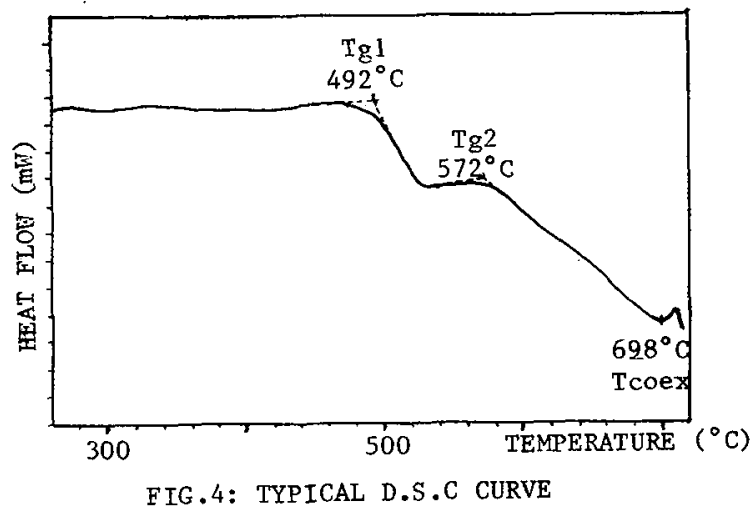

Microstructure and heat treatment : A calorimetric study was conducted with a 1090 Dupont DSC equipment. Three parameters can be deduced from the DSC curves - Fig. 4 -

$\mathrm{Tg}_{1}$ : correlated to the $\mathrm{Tg}$ measured by dilatometric method

$\mathrm{Tg} 2$ : assigned to the $\mathrm{Tg}$ of the silica rich phase

$\mathrm{T}_{\text {coex }}$ : coexistence temperature.

As shown in Table $I$ a variation of $\mathrm{Tg}_{1}$ and $\mathrm{T}$ coex cannot be seen distinctly with the heat treatment, whereas $\mathrm{Tg}_{2}$ displays the same behaviour as the mean pore radius (I) Fig. 5 -

(a)

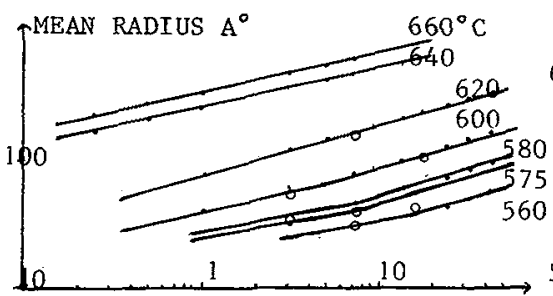

(b)

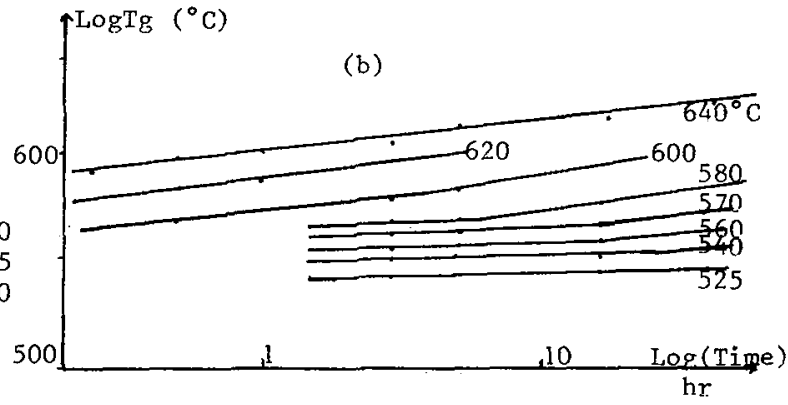

FIG.5: EVOLUTION OF MICROSTRUCTURE (a) AND $\mathrm{Tg}_{2}$ (b) VS HEAT TREATMENT 


\begin{tabular}{|c|c|c|c|c|}
\hline $\begin{array}{c}\text { Températurt } \\
{ }^{\circ} \mathrm{C}\end{array}$ & $\begin{array}{c}\text { Temps } \\
h .\end{array}$ & $\begin{array}{l}\mathrm{Tg}_{3} \\
{ }^{\circ} \mathrm{C}\end{array}$ & $\begin{array}{l}\mathrm{Tg}_{2} \\
{ }^{\circ} \mathrm{C}\end{array}$ & $\begin{array}{l}T_{\text {coex }} \\
{ }^{\circ} \mathrm{C}\end{array}$ \\
\hline 525 & $\begin{array}{r}3 \\
5 \\
17 \\
41\end{array}$ & $\begin{array}{l}486 \\
489 \\
488 \\
488\end{array}$ & $\begin{array}{l}542 \\
541 \\
544 \\
547\end{array}$ & $\begin{array}{l}691 \\
691 \\
691 \\
691\end{array}$ \\
\hline 540 & $\begin{array}{r}3 \\
5 \\
17 \\
41\end{array}$ & $\begin{array}{l}490 \\
489 \\
487 \\
486\end{array}$ & $\begin{array}{l}549 \\
549 \\
550 \\
554\end{array}$ & $\begin{array}{l}690 \\
691 \\
690 \\
691\end{array}$ \\
\hline 560 & $\begin{array}{r}3 \\
5 \\
17\end{array}$ & $\begin{array}{l}488 \\
489 \\
484\end{array}$ & $\begin{array}{l}552 \\
555 \\
558\end{array}$ & $\begin{array}{l}695 \\
695 \\
693\end{array}$ \\
\hline 570 & $\begin{array}{r}3 \\
5 \\
17 \\
41\end{array}$ & $\begin{array}{l}489 \\
489 \\
484 \\
488\end{array}$ & $\begin{array}{l}560 \\
564 \\
565 \\
573\end{array}$ & $\begin{array}{l}693 \\
691 \\
696 \\
697\end{array}$ \\
\hline 580 & $\begin{array}{r}3 \\
5 \\
17\end{array}$ & $\begin{array}{c}491 \\
489 \\
-\end{array}$ & $\begin{array}{l}567 \\
568 \\
575\end{array}$ & $\begin{array}{l}692 \\
695 \\
700\end{array}$ \\
\hline 600 & $\begin{array}{l}0,5 \\
3 \\
5\end{array}$ & $\begin{array}{l}489 \\
489 \\
489\end{array}$ & $\begin{array}{l}567 \\
579 \\
584\end{array}$ & $\begin{array}{l}593 \\
696 \\
695\end{array}$ \\
\hline 620 & $\begin{array}{l}0,5 \\
1 \\
3\end{array}$ & $\begin{array}{l}493 \\
491 \\
492\end{array}$ & $\begin{array}{c}584 \\
589 \\
-\end{array}$ & $\begin{array}{l}695 \\
696 \\
702\end{array}$ \\
\hline 640 & $\begin{array}{l}0,25 \\
0,5 \\
1 \\
3 \\
5 \\
17 \\
41\end{array}$ & $\begin{array}{l}492 \\
490 \\
492 \\
491 \\
492 \\
493 \\
493\end{array}$ & $\begin{array}{l}592 \\
500 \\
603 \\
606 \\
615 \\
619 \\
628\end{array}$ & $\begin{array}{c}697 \\
698 \\
700 \\
702 \\
704 \\
- \\
-\end{array}$ \\
\hline
\end{tabular}

TABLE 1: $\mathrm{Tg}_{1}, \mathrm{Tg}_{2}$, Tcoex VAIJUES VS HEAT TREATMENT

Up to $23 \%, \mathrm{GeO}_{2}$ does not fundamentally change the rôle of $\mathrm{Na}_{2} \mathrm{O}$ and $\mathrm{B}_{2} \mathrm{O}_{3}$ in the phase separation by spinodal decomposition as in the case of Vycor ${ }^{\mathrm{R}}$.

Leaching of the glass : A germanium radial concentration profile appears during the acid attack of the phase separated glass - Fig. 6 - due to diffusion (4). The concentration difference $\Delta c$ between the center $\mathrm{Cc}$ and the border of rod $\mathrm{Cb}$ tends to zero when the time increases to infinity, whereas $\mathrm{Cb}$ tends to a finite value - Fig. 7 Some part of germanium always remains in the silica phase. $\mathrm{Cb}$ and $\mathrm{Cc}$ values depend upon the leaching conditions - Fig. 7 -

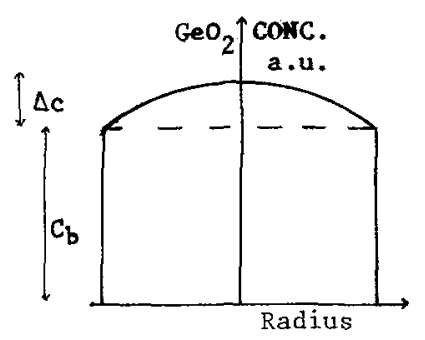

FIG. 6 : RADIAL CONCEN-

TRATION PROFIL AFTER

LEACHING. 


\begin{tabular}{|c|c|c|c|c|c|c|}
\hline \multirow{2}{*}{ GLASS } & \multicolumn{4}{|c|}{ COMPOSITION MOL $\%$} & \multirow{2}{*}{$\begin{array}{c}\text { LONGUE IJR } \\
\text { Ge-0 }\end{array}$} & \multirow{2}{*}{ OBSERVATIONS } \\
\hline & $\mathrm{SiO}_{2}$ & $\mathrm{GeO}_{2}$ & $\mathrm{~B}_{2} \mathrm{O}_{3}$ & $\mathrm{Na}_{2} \mathrm{O}$ & & \\
\hline 1 & 0 & 100 & 0 & 0 & 1.73 & \\
\hline 2 & 36.5 & 63.5 & 0 & 0 & 1.73 & \\
\hline 3 & 87.5 & 12.5 & 0 & 0 & 1.73 & $\begin{array}{l}\text { GLASS COMPOSITION } \\
\text { AFTER LEACHING A }\end{array}$ \\
\hline 4 & 54 & 10 & 28 & 8 & 1.725 & GLASS A \\
\hline
\end{tabular}

TABLE II : Ge-O BOND LENGTH FOUR FOUR GLASSES

III. GERMANIUM COORDINATION

EXAFS studies were made to determine the germanium coordination (5). The Ge-0 bond lengths in different glasses are shown in Table II. The Ge-O bond length in glass A is the same as for vitreous $\mathrm{GeO}_{2}$. The addition of silica to germania does not change the germanium coordination (Table II, glasses 2 and 3). Ge in glass A remains fourfold coordinated in the base glass and in the final glass after acid leaching. Experiments on heat-treated glass are being carried out to determine the Ge coordination in the leachable phase.

ACID

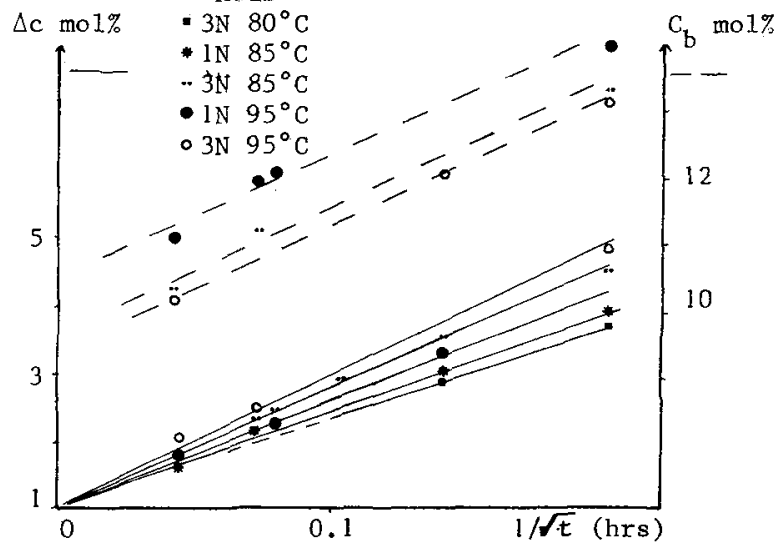

FIG.7: $\mathrm{GeO}_{2}$ CONCENTRATION WITH LEACHING DURATION

\section{REFERENCES :}

(1) F. GAUTHIER and J. GOMBERT, Non. Cryst. Solids 49 (1982) 157-163.

(2) G.W. MOREY, The properties of glass, Reinhold Ed, New York (1954).

(3) V. AKIMOV, The structure of glass, vo1 2, Trans. Consultant Bureau, New York (1960).

(4) J. GOMBERT, Propriêtés physico-chimiques des verres de borosilicates de sodium dopés à 1'oxyde de germanium, Université de Paris XI, Orsay (1979).

(5) C. LAPEYRE, J. PETIAU, G. CALAS, F. GAUTHIER and J. GOMBERT to be published in Bu11. Soc. Française Min. 